진행성 바티팽대부 선암종에서 카페시타빈과 옥살리플라틴 병합요법의 효과

국립암센터 췌담도암클리닉

이정환 · 김경희 · 우상명 · 박상재 · 한성식 · 홍은경 · 고영환 · 이주희 · 이우진

\title{
Effect of Capecitabine plus Oxaliplatin for Advanced Adenocarcinoma of Ampulla of Vater
}

Jung Hwan Lee, Kyung Hee Kim, Sang Myung Woo, Sang-Jae Park, Sung-Sik Han, Eun Kyung Hong, Young Hwan Koh, Ju Hee Lee, Woo Jin Lee

Pancreatobiliary Cancer Clinic, National Cancer Center, Goyang, Korea

Background/Aim: Adenocarcinoma arising from the ampulla of Vater is a rare disease and has limited data regarding outcome of palliative chemotherapy. We investigated the efficacy and safety of capecitabine plus oxaliplatin (XELOX) in patients with advanced ampullary adenocarcinoma.

Methods: From October 2006 to January 2014, we retrospectively analyzed 28 patients with advanced ampullary adenocarcinoma treated by XELOX regimen at single institution. All the patients had histologically confirmed stage IV or recurrent ampullary adenocarcinoma. XELOX was administered in outpatient clinic every 3 weeks according to the following protocol: oral administration of capecitabine $750 \mathrm{mg} / \mathrm{m}^{2}$ twice a day on days 1-14 and intravenous injection of oxaliplatin $130 \mathrm{mg} / \mathrm{m}^{2}$ on day 1 .

Results: With follow-up of median 24.6 months (range 4.0-78.0 months), median progression-free survival (PFS) was 4.8 months (range 0.7-26.1 months), and median overall survival (OS) was 11.9 months (range 2.0-36.0 months). One patient (4\%) achieved complete response and 5 patients (18\%) showed partial response. There were no significant differences for PFS and OS according to response by chemotherapy. The most common grade 3 adverse events in patients were nausea and vomiting (10.7\%). There was no treatment-related mortality.

Conclusions: XELOX regimen is well tolerated and show moderate activity against advanced ampullary adenocarcinoma.

Korean J Pancreas Biliary Tract 2017;22(3):127-133

Keywords: Adenocarcinoma, Ampulla of Vater, Capecitabine, Oxaliplatin, Antineoplastic agents $\begin{array}{ll}\text { Received } & \text { Mar. 6, 2017 } \\ \text { Revised } & \text { Apr. 7, 2017 } \\ \text { Accepted } & \text { Apr. 7, 2017 }\end{array}$

Corresponding author : Sang Myung Woo

Pancreatobiliary Cancer Clinic, National Cancer Center, 323 IIsan-ro, Ilsandong-gu, Goyang 10408 , Korea

Tel. +82-31-920-1733 Fax. +82-31-920-2798

E-mail; wsm@ncc.re.kr 


\section{서 론}

바터팽대부암은 흔하지 않은 악성 신생물 중 하나이며, 1985년과 2005년 사이에 미국에서 바터팽대부암 발병률은 남 성 10,000 명 당 0.7 명, 여성 10,000 명 당 0.4 명으로 전체 위장관 악성 종양의 $0.5 \%$ 를 차지하였다. ${ }^{1}$ 국내 통계에서는 췌장암이 나 담낭 및 담도암에 포함되어 있어 정확한 통계는 아직 밝혀 지지 않는 실정이다. 그러나 팽대부 주위에서 발생하는 종양 의 7-30\% 정도를 차지하며 팽대부 주위에서 발생하는 종양 중 두 번째로 흔한 종양이다..$^{2-4}$

다른 팽대부 주위 선암종과 비교하여, 바터팽대부 선암종은 절제 가능성이 더 높기 때문에 상대적으로 예후가 좋다. 근치 적 절제술을 받은 환자 중 5년 생존율은 35-46\%로 원위부 담 도암(5년 생존율 24-27\%) 또는 췌두부암(5년 생존율 약 15\%) 보다 우수하다. ${ }^{1,47}$ 바터 팽대부암이 드물기 때문에 진행성 암 은 종종 담도암(biliary tract cancer) 또는 소장 선암종을 위해 고안된 항암화학요법을 사용하여 치료한다. National Comprehensive Cancer Network (NCCN) 가이드라인에서는 대장 암에서 사용하는 folic acid, 5-fluorouracil (5-FU), oxaliplatin (FOLFOX) 또는 folic acid, 5-FU 및 irinotecan (FOLFIRI)이 나, FOLFOX 혹은 FOLFIRI와 bevacizumab 병합요법을 소장 선암종에 대한 항암화학요법으로 치료할 것을 권장하고 있으 며, 담도암에서는 gemcitabine과 cisplatin 병합요법으로 치료 할 것을 권고하고 있다. ${ }^{8}$ 그러나 진행성 바터팽대부 선암종을 담도암으로 취급되어야 하는지 또는 소장 선암종으로 취급되 어야 하는지는 현재 불확실하며, 명확한 가이드라인도 없는 상태이다.

5-FU의 경구형인 capecitabine은 종양내 고농도의 thymidine phosphorylase의 이용하여 종양 조직에서 5-FU를 우선적 으로 생성하도록 고안된 fluoropyrimidine 계열의 약제이다. ${ }^{9}$ Capecitabine과 oxaliplatin (XELOX) 병합요법은 2상 연구에 서 12 명의 진행된 소장 선암종 및 바터팽대부 선암종환자를 대상으로 $33 \%$ 의 관해율을 보였다. ${ }^{10}$ 이런 소규모 전향적 연구 외에는 진행성 암에 대해 20 명 안팎의 환자에서 항암화학요법 을 받은 환자들을 조사한 후향적 연구밖에 없고, 특히 재발하 거나 다른 항암화학치료에 실패한 이후 XELOX 병합요법의 성적에 대해서는 아직 신뢰할 만한 데이터가 없는 실정이 다. ${ }^{11,12}$ 따라서 저자들은 바터팽대부 선암종의 XELOX 병합요 법을 받은 환자들을 대상으로 XELOX 병합요법의 효과 및 안 전성을 분석하였다.

\section{방 법}

\section{1. 환자군}

2006년 10월부터 2014년 1월까지 기관내 데이터베이스에서 후향적으로 분석하였다. 재발성 또는 전이성(4기) 바터팽대부 선암종으로 진단받고, XELOX 병합요법으로 항암화학요법을 받은 환자들을 추출하였다. 치료를 받는 모든 환자는 활동도 (Eastern Cooperative Oncology Group performance status)에 서 0-2의 상태를 보였고, 시행 전 혈액학적, 영상학적 검사에 서 이상소견을 보이지 않았다. 이 연구는 국립암센터(National Cancer Center Hospital, Goyang, Korea)의 기관윤리위원회의 승인을 받았으며 1964년 헬싱키 선언(Declaration of Helsinki) 을 준수하여 수행되었다(NCC2017- 0047).

\section{2. 치료}

XELOX 병합요법은 oxaliplatin $130 \mathrm{mg} / \mathrm{m}^{2}$ 을 1일 2-4시간 동안 정맥내 투여하였고, capecitabine $750 \mathrm{mg} / \mathrm{m}^{2}$ 는 14 일간 매 일 2회 경구 투여하였다. 항암화학요법은 외래에서 주로 투여 하였고, 2 주 투약 후 1 주 휴약하는 3 주간의 기간을 1 주기로 진 행하였다. 항암화학요법 후 치료반응은 Response Evaluation Criteria in Solid Tumors (RECIST) guidelines (version 1.1) 기 준에 의해 결정되었다. 종양반응을 평가하기 위해 치료 전, 치 료 후 3 주기 간격으로 컴퓨터전산화단층촬영(computed tomography)과 흥부 X선 검사를 시행하였다. 일반혈액 검사, 생 화학 검사 등을 치료하는 동안이나 다음 치료과정 시작 전에 점검하였다. 신체상태가 악화되거나 혈액학적 검사에서 회복 이 느린 환자에서는 기준 용량의 $25 \%$ 를 각각 감량하여 사용 하였다. XELOX 병합요법은 종양의 진행이 일어나거나, 환자 가 받아들일 수 없는 독성을 나타내거나, 추가 항암화학요법 을 거부할 때까지 계속되었다. 투여량의 변경 및 치료지연은 관찰된 약물 관련 독성 및 주치의의 평가에 근거하였다. 이상 반응은 Common Terminology Criteria for Adverse Events (version 3.0)에 의해 평가하였다. ${ }^{13}$

\section{3. 통계 분석}

치료 결과는 관해율(response rate), 무진행 생존 기간(progression-free survival) 및 전체 생존 기간(overall survival)로 평가하였다. 무진행 생존 기간은 항암화학요법의 시작에서 질 병의 진행, 또는 모든 원인으로 인한 사망까지의 시간으로 정 의하였다. 전체 생존 기간은 항암화학요법으로부터 사망 또는 
가장 최근의 추적 관찰까지의 시간으로 정의되었다. 무진행 생존 기간과 전체 생존 기간은 Kaplan-Meier 생존분석을 사용 하여 추정하였으며, 유의 수준 $(p<0.05)$ 은 Log-rank test를 사 용하여 결정하였다. 모든 통계 분석은 STATA (ver. 14.0; STATA Corp., College Station, Tx, USA)를 사용하였다.

\section{결 과}

\section{1. 환자 특성}

환자의 특성을 Table 1 에 요약하였다. 총 28 명의 환자가 연 구에 포함되었다. 남자와 여자는 각각 16명(57\%)과 12명 (43\%)이었다. 환자의 중앙연령은 60세(범위 43-78세)였다. 17 명 $(61 \%)$ 환자에서 활동도가 0,10 명 $(36 \%)$ 에서 1,1 명(3\%)에 서 2 로 나타났다. 21 명 $(82 \%)$ 의 환자는 고분화(well-differentiated) 선암종이 나타났다. 5 명 $(18 \%)$ 의 환자에서 진단 당시 4 기 종양이었고, 23 명 $(82 \%)$ 에서 수술 후 재발한 환자였다. 이 중 11 명 $48 \%$ )의 환자는 수술 후 동시항암화학방사선치료(concurrent chemoradiotherapy)를 시행받았다. 4 명(17\%)의 환자 가 보조적 항암화학치료를 시행받았고, 1 명(4\%)의 환자에서 보조적 방사선치료만을 시행받았다. 재발한 환자 중 4 명 (17\%)에서 국소 구역 재발(loco-regional recurrence)이 발견되 었고, 19 명 $(83 \%)$ 에서 원격 전이가 발견되었다. 모든 대상 환자 에서 전이된 부위는 림프절 전이가 가장 많았다(19명, $68 \%$ ).

\section{2. 치료 효과와 이상반응}

최소 1 주기의 XELOX 병합요법이 모든 환자에게 투여되었 고, 중앙값 24.6개월(범위 4.0-78.0개월) 동안 환자들을 추적관 찰하였다. RECIST 기준에 의한 치료반응은 1 명 $(4 \%)$ 에서 완 전 관해(complete response)를 보였다(Fig. 1). 다섯 명(18\%)에 서 부분 관해(partial response)을 보였다. 16명(57\%)의 환자에 서는 안정성 병변(stable disease)이었으며, 3 명(14\%)의 환자 에서 진행되었다. 세 명 $(7 \%)$ 에서는 추적관찰이 되지 않아 반 응을 평가할 수 없었다. 관해율(overall response rate, complete response plus partial response)은 22\%였다(Table 2).

중앙 생존 기간(median overall survival)은 11.9개월(범위 2.0-36.0개월)이며, 중앙 무진행 생존 기간(median progression-free survival)은 4.8개월(범위 0.7-26.1개월)이었다(Fig. 2). 관해한 환자군(responder)과 관해하지 않는 환자군의 중앙 생 존 기간은 각각 24.3 개월, 11.5 개월이었으며, 중앙 무진행 생존 기간은 7.1 개월과 4.7 개월이었지만 통계적으로 유의하지 않았
다(Fig. 3).

가장 흔한 부작용은 구토 및 구역(6명, $21 \%)$ 이었으며, 신경 병증(6명, $21 \%$ )과 혈소판감소증(6명, $21 \%)$ 이 흔하게 관찰되었 다(Table 3). 아홉 명 $(36 \%)$ 의 환자에서 3 등급 부작용이 나타났

Table 1. Clinical characteristics of the patients treated by capecitabine plus oxaliplatin (XELOX)

\begin{tabular}{|c|c|}
\hline Variable & No. of patients \\
\hline Median age (range, year) & $60(43-78)$ \\
\hline \multicolumn{2}{|l|}{ Sex } \\
\hline Male & $16(57)$ \\
\hline Female & $12(43)$ \\
\hline \multicolumn{2}{|l|}{ ECOG performance } \\
\hline 0 & $17(61)$ \\
\hline 1 & $10(36)$ \\
\hline 2 & $1(3)$ \\
\hline \multicolumn{2}{|l|}{ Differentiation } \\
\hline Well differentiated & $7(25)$ \\
\hline Moderately differentiated & $16(57)$ \\
\hline Poorly differentiated & $5(18)$ \\
\hline \multicolumn{2}{|l|}{ Tumor status } \\
\hline Stage IV at initial evaluation & $5(18)$ \\
\hline Recurrence & $23(82)$ \\
\hline \multicolumn{2}{|l|}{ Prior treatment before XELOX } \\
\hline Operation & $7(31)$ \\
\hline Operation + CCRT & $11(48)$ \\
\hline Operation + chemotherapy & $4(17)$ \\
\hline Operation + radiotherapy & $1(4)$ \\
\hline \multicolumn{2}{|l|}{ Extent of recurred disease* } \\
\hline Locally advanced & $4(17)$ \\
\hline Metastasis & $19(83)$ \\
\hline \multicolumn{2}{|l|}{ Site of metastasis } \\
\hline Lymph node & $19(68)$ \\
\hline Liver & $17(61)$ \\
\hline Lungs & $5(18)$ \\
\hline Operation site & $4(14)$ \\
\hline Bone & $2(7)$ \\
\hline Others & $6(21)$ \\
\hline
\end{tabular}

Values are presented as number (\%).

No., number; ECOG, Eastern Cooperative Oncology Group; CCRT, concurrent chemoradiotherapy.

*Locally advanced disease means radiologically diagnosed peripancreatic extension without distant metastasis. 

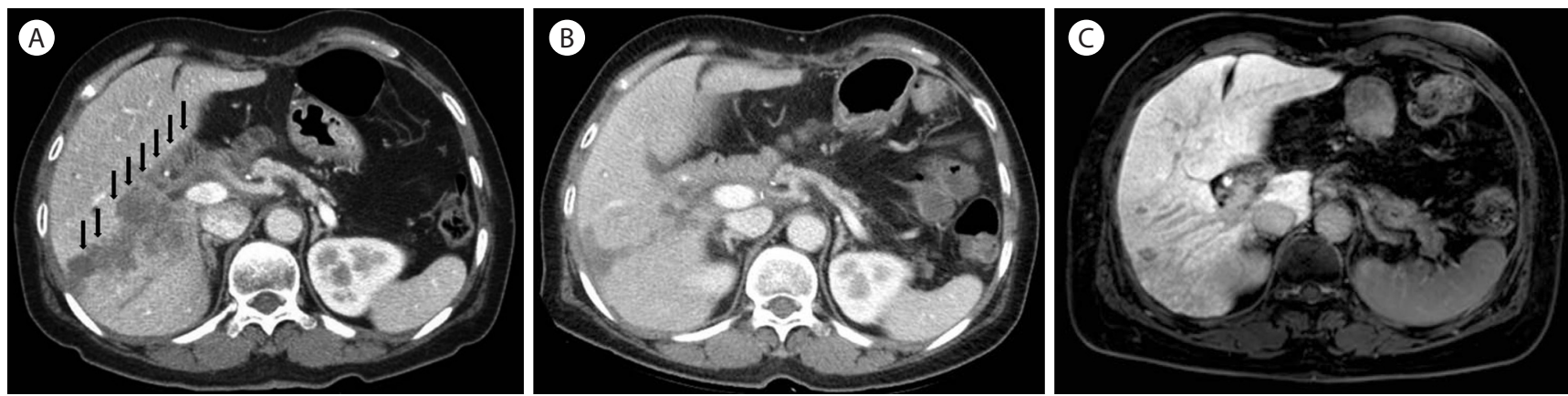

Fig. 1. A 62 year-old women showed complete response to capecitabine plus oxalipatin (XELOX). (A). Enhanced compute tomography before treatment. There were periportal spreading liver metastasis, and tumor invasion at choledocojejunostomy site (arrows). (B). Enhanced compute tomography performed after first cycle of XELOX. There was decrease in the size of periportal liver metastasis. (C). Magnetic resonance imaging, which was performed after fifteenth cycle of XELOX, showed disappearance of liver metastasis.

Table 2. Tumor response to chemotherapy

\begin{tabular}{lc}
\hline Tumor response & Value \\
\hline Complete response & $1(4)$ \\
Partial response & $5(18)$ \\
Stable disease & $16(57)$ \\
Progressive disease & $3(14)$ \\
Follow-up loss & $3(7)$ \\
$\begin{array}{l}\text { Overall response rate } \\
\text { (complete response plus partial response) }\end{array}$ & $6(22)$ \\
\hline
\end{tabular}

Values are presented as number (\%).

으며 구토 및 구역(3명, $11 \%)$, 수족구증( 2 명, $7 \%$ ), 혈소판감소증 (2명, $7 \%$ ), 호중구감소증(1명, $4 \%$ ), 빈혈(1명, $4 \%$ ) 순으로 나타 났다. 4 도 이상의 부작용이나 치료로 인한 사망 환자는 없었다.

\section{고 찰}

바터팽대부암 자체가 많지 않으며, 이에 관한 임상적 연구 또한 많지 않다. 바터팽대부암를 가진 환자는 전형적으로 황 달과 같은 임상증상의 조기 출현으로 비교적 초기 단계에서 진단되며 절제 가능성은 상대적으로 높다. ${ }^{14,15}$ 반면에 진행된 바터팽대부암는 연구된 바가 많지 않으며, 특히 진행성 병기의 항암화학요법의 치료 결과에 대해서는 알려진 바가 많지 않 다. 본 연구에서 진행되거나 재발한 바터팽대부 선암종 환자에 서 28 명의 환자들을 XELOX 요법으로 치료하였을 때, 중앙 무 진행 생존 기간은 4.8 개월이었고 중앙 생존 기간은 11.9 개월이 었으며, 관해율은 $22 \%$ 였다. 3 단계 이상의 이상반응은 오심 및 구토가 $10.7 \%$ 로 나타났으며, 부작용으로 인한 사망은 없었다.
1 명의 환자에서 완전 관해를 보였는데, 2012년 2월 유문부 보 존 췌두부절제술을 시행받고, 수술 후 동시항암화학방사선치 료를 시행받았다(5,040 cGy/28 fraction). 수술 후 7개월간의 우엽후하구역(S6)에 전이가 발견되어, 고주파열치료술(radiofrequency ablation)을 시행하였고, 그 후 15차례에 걸쳐 고식 적 XELOX 병합요법으로 치료받았다. XELOX 병합요법으로 치료받은 시점부터 마지막 외래 추적까지 28.7개월 동안 재발 의 증거는 발견되지 않고 있다. 국내 연구에서 진행성 바터팽 대부 선암종 21명을 대상으로 한 XELOX 병합요법에 대한 효 과를 고찰할 때, 2 명(9\%)이 완전 관해를 보였고, 진행성 소장 선암종과 바터팽대부 선암종을 대상으로 한 XELOX 병합요법 국외 2 상 연구에서도 3 명(10\%)에서 완전 관해를 보였다. ${ }^{10,16}$

이전에 cisplatin 계열의 항암화학요법(5-FU과 cisplatin 또는 gemcitabine과 cisplatin 병합요법)이 29명의 진행성 바터팽대 부 선암종 환자에서 결과가 보고된 바가 있다. ${ }^{11} 27.5 \%$ 의 관해 율과 $72.4 \%$ 의 질병통제율(disease control rate)을 보였고, 질병 의 진행까지의 중앙값은 4.9 개월, 중앙 생존 기간은 12.5 개월이 었다. 다른 연구에서는 tegafur를 포함한 platinum 계열의 화학 요법을 사용하였는데, $7.7 \%$ 의 관해율과 질병의 진행까지의 중 앙값은 3.2개월, 중앙 생존 기간은 9.1개월로 실망스런 결과를 보여주었다. ${ }^{12}$

바터팽대부 선암종의 경우, 항암화학요법을 선택할 때 보통 담도암 또는 소장 선암종에 해당하는 화학요법이 쓰이지만, 바터팽대부 선암종에 가장 적합한 화학요법은 아직 정립되지 않았다. 이전의 연구에서는, 바터팽대부 선암종이 진행성 소 장 선암종과 같이 포함되어 이에 대한 두 개의 전향적 2 상 연 구가 있다. 먼저 38 명의 환자에서 5-FU, doxorubicin 및 mitomycin C (FAM)를 34명의 진행성 소장 선암종과 4명의 바터 

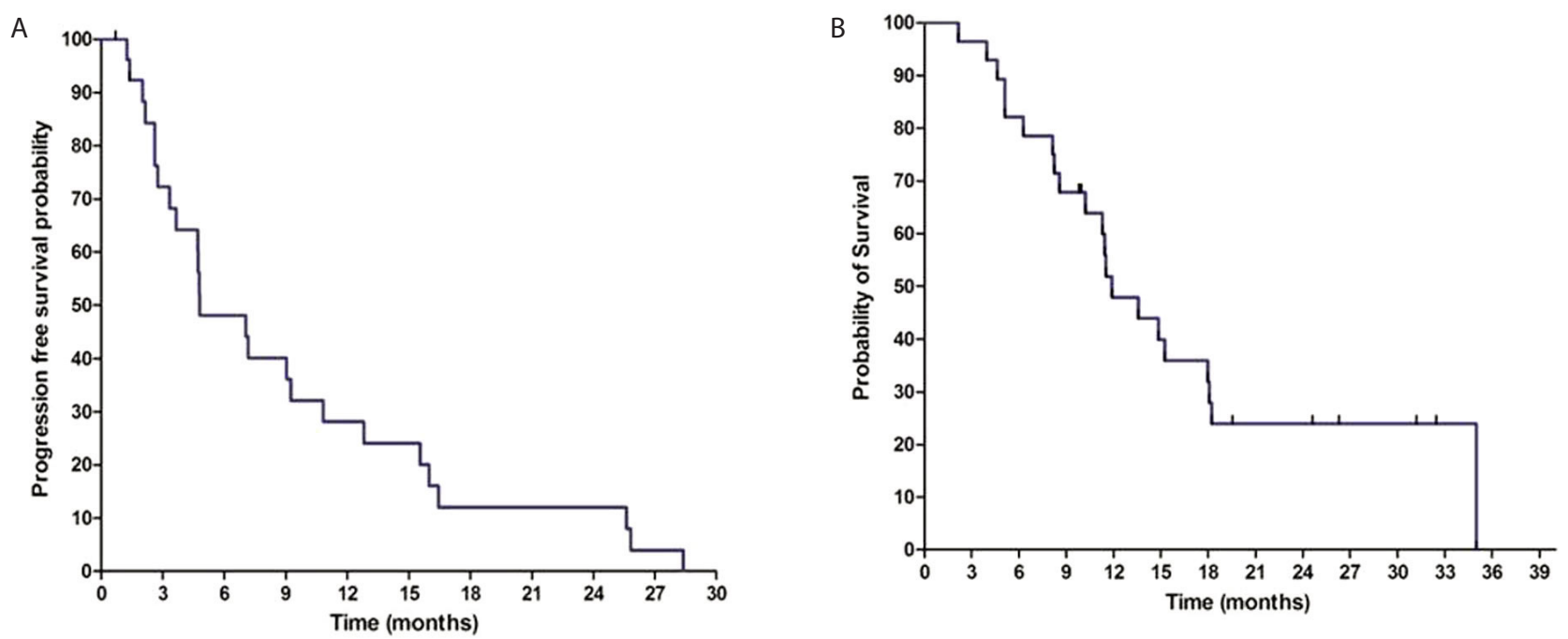

Fig. 2. Progression free survival curve (A) and overall survival curve (B) calculated using the Kaplan-Meier method for all patients.
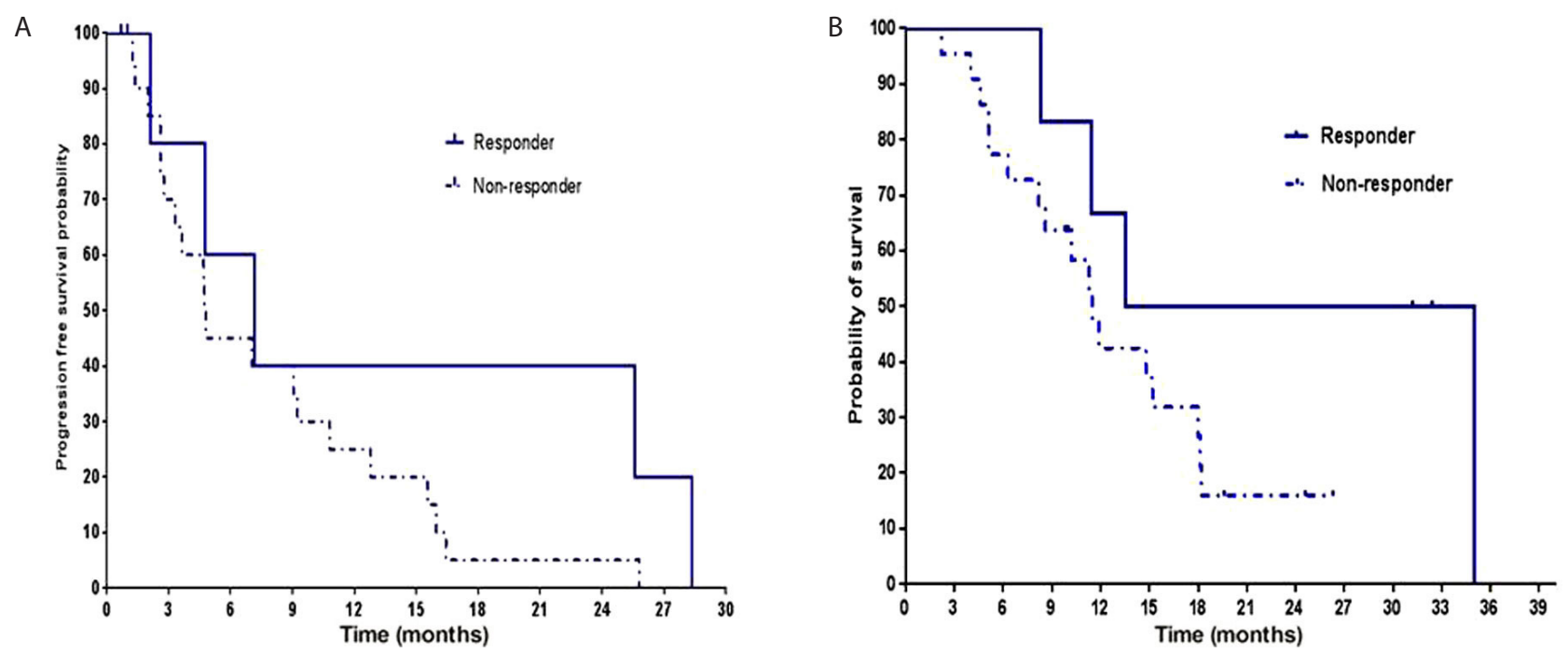

Fig. 3. Progression free survival curve (A) and overall survival curve (B) calculated using the Kaplan-Meier method for groups between responders and non-responders.

팽대부 선암종을 대상으로 치료하였을 때 $18 \%$ 의 낮은 관해율 을 보였고, 중앙 생존 기간은 8 개월이었다. ${ }^{17}$ 바터팽대부 선암 종 환자만의 중앙 생존 기간은 7 개월로 소장 선암종 환자와 비슷한 결과를 보였다. 두 번째 연구에서는 XELOX 병합요법 을 투여한 환자 30 명을 대상으로 하였는데, 18 명의 소장 선암 종과 12 명의 바터팽대부 선암종이 포함되었고 전체 관해율은 $50 \%$ 였으며, 20.4 개월의 중앙 생존 기간을 보였다. ${ }^{10}$ 그러나 진 행성 바터팽대부 선암종에 대한 관해율은 $33 \%$ 로 소장 선암종 의 $61 \%$ 보다 낮았다. 이 관해율은 담도암을 XELOX 병합요법 으로 치료한 경우와 유사하였다. ${ }^{18}$ 아직 바터팽대부 선암종을
소장 선암종으로 치료해야 하는지 아니면 담도암으로 치료해 야 하는지 분명하지는 않지만, 주요 임상시험이나 후향적 연 구는 담도암의 하위그룹으로 바터팽대부 선암종을 분류하고 있다. 담도암에서 gemcitabine과 cisplatin 병합요법의 우월성 을 보고한 3상 무작위대조연구에서는 20 명 $4.9 \%)$ 의 진행성 바터팽대부 선암종 환자가 포함되었다. ${ }^{19}$ 하위 집단 분석에서 항암요법 효과의 차이는 유의하지 않았지만, gemcitabine과 cisplatin 병합요법은 gemcitabine 단독투여군보다 긴 생존 기 간을 보였다(hazard ratio, 0.62 ; 95\% confidence interval 0.211.81). Fluoropyrimidine 계열의 항암화학요법과 gemcitabine 
Table 3. Treatment-related toxicities

\begin{tabular}{llll}
\hline \multirow{2}{*}{ Toxicity } & \multicolumn{3}{c}{ Value } \\
\cline { 2 - 4 } & Grade 1 & Grade 2 & Grade 3 \\
\hline Hematologic & & 0 & $1(4)$ \\
Neutropenia & 0 & $1(4)$ & $1(4)$ \\
Anemia & $4(14)$ & 0 & $2(7)$ \\
Thrombocytopenia & & & \\
Non-hematologic & $1(4)$ & 0 & $2(7)$ \\
Hand foot syndrome & $3(11)$ & 0 & 0 \\
Diarrhea & $4(14)$ & $2(7)$ & 0 \\
Neuropathy & $3(11)$ & 0 & $3(11)$ \\
Nausea, vomiting & $1(4)$ & $1(4)$ & 0 \\
Anorexia & $1(4)$ & 0 & 0 \\
Itching & 0 & $2(7)$ & 0 \\
Constipation & 0 & $1(4)$ & 0 \\
Fatigue & & & \\
\hline
\end{tabular}

Values are presented as number (\%).

계열의 항암화학요법은 둘 다 쓰일 수 있지만, 어느 것이 우월 한지는 불분명하다. 최근 후향적 연구에서는 진행성 바터팽대 부 선암종에 대해 fluoropyrimidine 계열의 항암화학요법은 gemcitabine 계열의 항암화학요법에 비해 무진행 생존 기간이 더 나은 것을 보여주었지만, 이에 대한 전향적 연구가 필요하 다(각각 9.2 개월, 3.4 개월; $p=0.006$ ). ${ }^{20}$

바터팽대부는 십이지장 상피, 췌관 상피 및 담관 상피와 같 은 세 가지 상피 요소로 구성된다. 최근 연구들은 병리학적 표 현형을 분류하는 것이 중요하다는 것을 보여주고 있는데, 바 터팽대부 선암종은 두 개의 조직학적 표현형, 즉 장형(intestinal type)과 췌담도형(pancreatobiliary type)으로 나뉠 수 있 다. ${ }^{21,22}$ 장형 바터팽대부 선암종은 $50-80 \%$ 을 차지하며, 췌담도 형과 비교하여 예후가 좋다고 알려져 있다. ${ }^{21} \mathrm{CDX} 2$ 및 MUC2 발현은 장형과 췌담도형을 구별하는데 도움이 된다. ${ }^{23}$ 그러나 진행된 바터팽대부 선암종에서 조직학적 표현형에 따라 분석 된 항암화학요법의 결과는 아직 없는 상태이다. XELOX 병합 요법을 시행받은 21 명 환자를 대상으로 한 후향적 연구에서 장형 환자에서 췌담도형 환자보다 더 나은 중앙 무진행 생존 기간을 보였다(각각 13.1 개월, 6.4 개월; $p=0.038$ ). ${ }^{16}$ 그러나 또 다른 소규모 연구에서는 결과가 일치하지 않아(각각 2.5개 월, 3.5 개월) 추가 연구가 필요하다. ${ }^{12}$

본 연구는 소규모의 환자를 대상으로 후향적으로 분석되었 고, 다른 치료요법과 비교하지 못하였다. 또 연구 기간이 8년
정도로 길었다는 점 등이 이번 연구의 제한점이라고 할 수 있 다. 이에 대해서는 향후 좀 더 많은 연구가 이루어져야 할 것으 로 생각한다.

결론적으로 XELOX 병합 항암화학요법은 진행성 바터팽대 부 선암종에서 비교적 높은 관해율을 나타내었고, 독성과 부 작용도 비교적 낮았다. 따라서 XELOX 병합 항암화학요법은 재발하거나 진행한 바터팽대부 선암종 환자에서 선택할 수 있 는 항암화학요법 중 하나이나, 향후 좀 더 많은 수의 환자를 대 상으로 하는 전향적 연구가 필요하다.

\section{요 약}

배경/목적: 바터팽대부에서 발생하는 선암종은 드문 질환 으로 항암화학요법에 대한 연구가 부족하다. 본 연구에서 진 행성 바터팽대부 선암종 환자에서 XELOX 병합요법의 효능 및 안전성을 분석하고자 한다.

방법: 2006년 10월부터 2014년 1월까지 국립암센터에서 XELOX 병합요법으로 치료한 바터팽대부 선암종 환자 28명 을 대상으로 후향적으로 분석하였다. 모든 환자는 진단 당시 전이성 또는 재발한 바터팽대부 선암종 환자이었다. XELOX 병합요법은 외래에서 3 주마다 다음과 같은 프로토콜에 따라 투여되었다. 치료 시작 1-14일에 하루 2회 카페시타빈 750 $\mathrm{mg} / \mathrm{m}^{2}$ 를 경구 투여하고, 1 일에 옥살리플라틴 $130 \mathrm{mg} / \mathrm{m}^{2}$ 을 정맥 주사하였다.

결과: 24.6개월(범위 4.8-78개월)의 중앙 추적관찰 기간에서 중앙 무진행 생존 기간은 4.8개월(범위 0.7-18.0개월)이었고, 중앙 생존 기간은 11.9 개월(범위 2.0-26.1개월)이었다. 1 명의 환자(4\%)가 완전 관해를 얻었고, 5 명의 환자( $18 \%)$ 는 부분 관 해를 보였다. 무진행 생존 기간와 전체 생존 기간에서 항암화 학요법 반응 여부에 따른 차이는 없었다. 환자에서 가장 흔한 3 등급의 이상 반응은 메스꺼움과 구토였다(10.7\%). 치료와 관 련된 사망은 관찰되지 않았다.

결론: XELOX 요법은 전이 혹은 재발 바터팽대부 선암종에서 비교적 낮은 독성의 발현과 중등도 효과를 보이는 치료법이다.

국문 색인: 선암종, 바터팽대부, 카페시타빈, 옥살리플라틴, 항암제

\section{Conflicts of Interest}

The authors have no conflicts to disclose. 


\section{Acknowledgments}

The present study was supported by grants from the $\mathrm{Na}$ tional Cancer Center, Korea (Grant number, 1610040-2).

\section{REFERENCES}

1. Chareton B, Coiffic J, Landen S, Bardaxoglou E, Campion JP, Launois B. Diagnosis and therapy for ampullary tumors: 63 cases. World J Surg 1996;20:707-712.

2. Howe JR, Klimstra DS, Moccia RD, Conlon KC, Brennan MF. Factors predictive of survival in ampullary carcinoma. Ann Surg 1998;228:87-94.

3. Nakase A, Matsumoto Y, Uchida K, Honjo I. Surgical treatment of cancer of the pancreas and the periampullary region: cumulative results in 57 institutions in Japan. Ann Surg 1977;185:52-57.

4. Yeo CJ, Sohn TA, Cameron JL, Hruban RH, Lillemoe KD, Pitt HA. Periampullary adenocarcinoma: analysis of 5-year survivors. Ann Surg 1998:227:821-831.

5. Miyakawa S, Ishihara S, Horiguchi A, Takada T, Miyazaki M, Nagakawa T. Biliary tract cancer treatment: 5,584 results from the Biliary Tract Cancer Statistics Registry from 1998 to 2004 in Japan. J Hepatobiliary Pancreat Surg 2009;16:1-7.

6. Monson JR, Donohue JH, McEntee GP, et al. Radical resection for carcinoma of the ampulla of Vater. Arch Surg 1991;126:353-357.

7. Roder JD, Schneider PM, Stein HJ, Siewert JR. Number of lymph node metastases is significantly associated with survival in patients with radically resected carcinoma of the ampulla of Vater. Br J Surg 1995;82:1693-1696.

8. National Comprehensive Cancer Network (NCCN). Clinical Practice Guidelines in Oncology; Hepatobiliary cancer [Internet]. NCCN; 2017 [updated 2017 March 25]. Available from: https://www.nccn.org/professionals/physician_gls/pdf/hepatobiliary.pdf.

9. Miwa M, Ura M, Nishida M, et al. Design of a novel oral fluoropyrimidine carbamate, capecitabine, which generates 5 -fluorouracil selectively in tumours by enzymes concentrated in human liver and cancer tissue. Eur J Cancer 1998;34:1274-1281.

10. Overman MJ, Varadhachary GR, Kopetz S, et al. Phase II study of capecitabine and oxaliplatin for advanced adenocarcinoma of the small bowel and ampulla of Vater. J Clin Oncol 2009;27:2598-2603.
11. Kim ST, Lee J, Lee KT, et al. The efficacy of frontline platinum-based combination chemotherapy in advanced adenocarcinoma of the ampulla of Vater. Med Oncol 2010;27:1149-1154.

12. Shoji H, Morizane C, Hiraoka N, et al. Twenty-six cases of advanced ampullary adenocarcinoma treated with systemic chemotherapy. Jpn J Clin Oncol 2014;44:324-330.

13. Trotti A, Colevas AD, Setser A, et al. CTCAE v3.0: development of a comprehensive grading system for the adverse effects of cancer treatment. Semin Radiat Oncol 2003;13:176-181.

14. Bouvet $M$, Gamagami RA, Gilpin EA, et al. Factors influencing survival after resection for periampullary neoplasms. Am J Surg 2000;180:13-17.

15. Klempnauer J, Ridder GJ, Pichlmayr R. Prognostic factors after resection of ampullary carcinoma: multivariate survival analysis in comparison with ductal cancer of the pancreatic head. Br J Surg 1995;82:16861691.

16. Kim HS, Shin SJ, Kim JH, Kim H, Choi HJ. Better outcome of XELOX chemotherapy in patients with advanced intestinal-type adenocarcinoma of the ampulla of Vater. Tohoku J Exp Med 2013;231:21-28.

17. Gibson MK, Holcroft CA, Kvols LK, Haller D. Phase II study of 5-fluorouracil, doxorubicin, and mitomycin C for metastatic small bowel adenocarcinoma. Oncologist 2005;10:132-137.

18. Nehls O, Oettle H, Hartmann JT, et al. Capecitabine plus oxaliplatin as first-line treatment in patients with advanced biliary system adenocarcinoma: a prospective multicentre phase II trial. Br J Cancer 2008;98:309-315.

19. Valle J, Wasan H, Palmer DH, et al. Cisplatin plus gemcitabine versus gemcitabine for biliary tract cancer. N Engl J Med 2010;362:1273-1281.

20. Jiang ZQ, Varadhachary $G$, Wang $X$, et al. A retrospective study of ampullary adenocarcinomas: overall survival and responsiveness to fluoropyrimidine-based chemotherapy. Ann Oncol 2013;24:2349-2353.

21. Fischer HP, Zhou H. Pathogenesis and histomorphology of ampullary carcinomas and their precursor lesions. Review and individual findings. Pathologe 2003;24:196-203.

22. Kimura W, Futakawa N, Yamagata S, et al. Different clinicopathologic findings in two histologic types of carcinoma of papilla of Vater. Jpn J Cancer Res 1994;85:161-166.

23. Chu PG, Schwarz RE, Lau SK, Yen Y, Weiss LM. Immunohistochemical staining in the diagnosis of pancreatobiliary and ampulla of Vater adenocarcinoma: application of CDX2, CK17, MUC1, and MUC2. Am J Surg Pathol 2005;29:359-367. 